\title{
Technology Assisted Language Learning is a silver bullet for enhancing Language competence and performance: A Case Study
}

\author{
Jameel Ahmad \\ GRC English, JCC, King Abdulaziz University, KSA \\ P.O. box 80283, Jeddah, 21589, Kingdom of Saudi Arabia \\ E-mail: jahmad1@kau.edu.sa
}

Received: 03-08-2016

Published: 10-12-2016
Accepted: 16-10-2016

doi:10.7575/aiac.ijalel.v.5n.7p.118
Advance Access Published: November 2016

URL: http://dx.doi.org/10.7575/aiac.ijalel.v.5n.7p.118

\begin{abstract}
Technology Assisted Language Learning (TALL) is an infallible means to develop profound knowledge and wide range of language skills. It instills in EFL learners an illimitable passion for task-based and skills oriented learning rather than rote memorization. New technological gadgets have commoditized a broad-based learning and teaching avenues and brought the whole learning process to life. A vast variety of authentic online- learning resources, motivational visual prompts, exciting videos, web-based interactivity and customizable language software, email, discussion forums, Skype, Twitter, apps, Internet mobiles, Facebook and YouTube have become obtrusive tools to enhance competence and performance in EFL teaching and learning realms. Technology can also provide various types of scaffolding for students learning to read. Nevertheless, instructors can also enhance their pedagogical effectiveness. However, the main focus of interest in this study is to ascertain to what extent the modern technological devices augment learners' competence and performance specifically in vocabulary learning, grammatical accuracy and listening/ speaking skills. The remarkable scores of empirical surveys conducted in the present study reveal that TALL does assist learners to improve listening / speaking skills, pronunciation, extensive vocabulary and grammatical accuracy. The findings also manifest that the hybridity, instantaneity and super-diversity of digital learning lay far-reaching impact on learners' motivation for learning and incredibly maneuver learners to immerse in the whole learning process.
\end{abstract}

Keywords: TALL learning, language skills, pedagogy, effectiveness, motivation, educators, learners

\section{Introduction}

\subsection{Statement of the Problem}

Saudi EFL learners have multiple challenges while learning English at tertiary level. The level of proficiency they need in English when they enter the college is abysmally low. More than 50\% students are unable to cope up with the required degree of proficiency they need in English at tertiary level. In fact, their prior exposure to English at school was at its nadir. Neither their home nor school environment were conducive for learning English. Therefore, majority of Saudi learners feel least inspired by their parents to focus on English as an inevitable tool for grooming their academic and professional careers. Besides, Saudi EFL learners completely ignore the significance of independent learning at home. However, they feel excited towards technology assisted language learning. They are obsessed with new breed of learning technologies such as smartphone, tablets, Facebook, Twitter, and You Tube. Besides, they have access to overhead projectors, interactive whiteboard, laptop computers and wireless Internet at tertiary level, because technological infrastructure of Saudi universities is up to the mark. EFL teachers in Saudi universities are also making the best use of these advanced technological devices and blended learning systems accessible to every EFL classroom. However, hardly any ground-breaking research was conducted regarding the impact of technology on Saudi EFL learners' aptitude for EFL learning. Some researchers have touched upon the topic but in-depth survey is really long overdue. The previously mentioned challenges that beset Saudi EFL learners increased my quest for intensive research on the said topic and in-depth analysis to explore some profound results. Therefore, the present research tends to explore how and to what extent the modern educational technologies enhance learners' language performance and educators' pedagogical competence. There is no doubt that a lot of research data showing the benefits of technologies in language teaching/ learning are available online but an exact statistical survey regarding the impact of digital use on Saudi EFL/ ESL learners and educators is still in infancy in Saudi universities. The idea to do research on the said topic occurred to me when I found frequent use of modern technologies in EFL/ ESL classes in Saudi universities. Therefore, to explore the contrastive attainment of technology assisted EFL learners and traditional learners has become the main motto of the present research.

Under the unified monolithic umbrella of TALL, numerous alternatives that have made their appearance in the last 15 years of English language teaching and learning are: Computer Assisted Language Learning (CALL),Computer Mediated Language Learning (CMLL), Web Based Language Learning (WBLL), Mobile Assisted Language Learning (MALL), Machine Translation Assisted Language Learning (MTALL), and so on. Moreover, the most recent among numerous electronic devices, which have significantly influenced all facets of human life, are Internet capable mobile 
phones, which are handy, flexible and can be used anytime and anywhere. The above-mentioned electronic devices offer a huge number of fantastic teaching and learning resources for phonology, morphology, grammar, vocabulary, integrated language skills and so forth. In the era of technology -enabled worldwide communication, neither teachers nor students can forego online learning and online teaching resources. Both teachers and learners use blogs to post their comments as a way of honing their communication skills. The worldwide diffusion of digital media has encouraged both educaters and lerners to use English on a daily basis to meet their academic and professional needs. This change has several concomitants for English language teachers to rethink how to integrate technology in teaching language skills. It is also interesting to note that today's students use technology not just as a powerful learning aid, but they also master technology as a medium of communication, research and knowledge production. The fact is that language and technology are highly intertwined in today's pedagogical scenario. The duo goes hand in hand and assists each other, thereby making the learners competent in both language and computer skills. If the learners are competent in both computer and language skills they can easily explore relevant websites, scan and skim contents, use word processors and computer-based tools such as spelling and grammar checkers to improve both linguistic knowledge and skills. With the help of these electronic resources, the learner can get opportunity to learn correct pronunciation, extensive vocabulary, communicative grammar and integrated language skills.

Mark Warschauer (2003) considers English as an effective tool to acquire knowledge in any discipline. According to him, "English is not an end in itself, but just a tool for being able to make the best use of information technology." In other words, both English and information technology are tools - to allow learners to share knowledge and skills worldwide. These technological devices also assist educators to enhance their instructional abilities. The ESL/ EFL teachers can combine language and technology to revolutionize the whole language learning process. This is undeniably true that if technology is fully integrated in EFL classrooms, the EFL learners, ipso facto, will attain language competence and performance. The use of computer games really fascinates EFL learners at all levels for learning linguistic knowledge and skills with fun and excitement. Digital Play, from Delta Publishing is available in the Kindle store where the EFL learners can download the free Kindle Reading App and ELT specialists can share their expertise with other ELT teachers about how to use technology to enhance EFL learners' proficiency in English. It also demonstrates how language games can engage and motivate EFL learners in the classrooms. WORDREADY is a significant interactive tool to improve word power of 7-12 year-old children. It encompasses all the important words related to day-to day communication.

TALL is an extraordinary inclusive and multifaceted mechanism, which assists all the teaching methodologies: old or new which were used over the decades to teach English as a foreign or as a second language. The modern technological devices substantiate the grammar translation method sometimes called traditional method for teaching Greek and Latin in the early 1500s. The grammar-translation method encourages the EFL learners to memorize grammatical rules of the target language and then apply those rules by translating sentences between the target language and the native language. This traditional method of teaching grammar has proven to be ineffective in modern pedagogical setup. On the contrary, Google translation serves as an effective interface between technology and learners. It equally assists both teachers and learners in the process of teaching and learning the language skills, grammar, vocabulary and pronunciation.Within fraction of second, the teacher can browse Google translation and can also display online images of diificult words to elucicidate their conceptual meanings to EFL/ ESL learners. In addition, technological devices offer a wide range of grammar exercises that really motivate students and facilitate their efforts to understand grammatical concepts and use them effectively in their daily conversation. The Internet allows learners more opportunities to practice online grammar quizzes on their own pace. In fact, the regular use of these devices in teaching and learning grammar has proven to be more effective than using textbooks. Miscellaneous software containing authentic grammar-activities along with explanations of grammatical rules and web-based instructional videos have enabled English teachers to create their own context based grammar exercises, thereby making their teaching more motivating and effective. EFL / ESL teachhers can also use some of the modern pedagogical e-learning systems such as, EMES, LMS and Edmodo and upload their own customized teaching materials to suit the levels and the needs of the students. In addition, both teachers and learners can benefit from the following websites: English Grammar.org, English Grammar Secrets, Using English.com, Learn English by British Council, English Club, Perfect English Grammar, English leap.com, English Teacher Melanie, Grammarly Handbook and English grammar exercises by Kaplan, and so on.

The modern technological devices play a significant role in teaching grammar communicatively and excitingly. While teaching present continuous tense, the teacher can show numerous online visual prompts containing different activities such as swimming, running, cooking, playing etc. and ask the students what they are doing. By answering the questions, the students can practise present continuous tense. Instead of telling the students to memorize the rules of grammar, the teacher should create different situations and ask students to frame different sentences that match well to the given situation. This way, the teacher can make students increasingly fluent and accurate in producing grammatically correct and situation based sentences.

TALL strongly supports the audio-lingual method which was based on B.F Skinner,s behaviorist theory of learning and widely used in the 1950s and 1960s, with special emphasis on drills to teach structural patterns, memorization of set phrases, pronunciation, intonation, teaching of vocabulary in context and reinforcement of correct responses. The basic assumption of this theory was that a learner responds to the environmental stimuli and his repeated response reinforces language learning. Some of the electronic learning resources are based on the foundation of behaviorism. Numerous language software have immense potential to give immediate feedback and encourage learners to follow trial and error concept of learning. If learners give incorrect responses, they receive a feedback and attempt the question once again to improve their mistakes. In addition, some software have simple drill/skill programs. For example, the website, Prentice 
Hall gives students an adequate opportunity to practice language a great deal.

Electronic devices substantially facilitate communicative language teaching which became prominent in the 1970s and 80s. Technology offers real-world language situations and motivates students to communicate with correct pronunciation. It boosts students' self-confidence, facilitates independent and self-paced learning and student-centered learning. It turns students more active and engaged. Technological tools can be used to bring more realistic language experiences to the blended learning environment. Since the teacher acts as a facilitator within this type of blended teaching, it is his/her role to find a variety of activities that act as a catalyst for authentic communication.

A plethora of language software such as TOEFL Mastery, Accelerated English, Rosetta Stones and multimedia programs for children such as Aesop's Fables and The Animals promote integrated language skills a great deal. In order to improve pronunciation, CALL includes Sounds American, Conversations, Firsthand Access and The Lost Secret. These learning resources enable EFL learners to record and playback their own voices and compare them to a model. CALL has also designed programs to improve learners' reading skills such as Reading Adventure 1 - ESL, MacReader, Reading Critically, Steps to Comprehension, and games (HangWord). CALL also improves vocabulary such as Synonyms, English Vocabulary, Hangman and Scrabble. Some software support writing skills such as Sentence Combining, Sentence Maker, and Typing Tutor. The most popular software in this domain is Daedalus Integrated Writing Environment, and Aspects and Mac Collaborator. The purpose for giving the names of these software is to make EFL teachers and students familiar with them so that they can use them in their leisure hours to improve their language skills.

\subsection{Literature Review}

Almost all the ELT practitioners, applied linguists, educationists and innovative EFL researchers have endorsed the effectiveness of new technologies in EFL learning and teaching scenario. They have admitted that the emergence of new technologies such as laptop computers, wireless Internet, Internet capable mobiles, whiteboards, EMES and overhead projectors have revolutionized the whole process of learning and teaching and opened up abundance of new exciting opportunities for EFL learners to learn integrated language skills more effectively. The EFL teachers have also evolved over the years to using World Wide Web, PowerPoint and podcasts to teach integrated language skills, communicative grammar and generative vocabulary. These groundbreaking pedagogical innovations encourage independent learning and engage learners with live audiences in real contexts. The ELT researchers since 1960 have been reflecting upon the numerous aspects of the usefulness of these new technologies in EFL teaching and learning situations. Since the very inception of the emergence of technologies, the linguists across the world have realized the significance of TALL in the teaching of integrated language skills. For example, Meskill \& Rangelova (1995) showed how the Internet, combined with other technologies, create an integrated communicative environment for EFL students in Bulgaria.The Bulgarian students were encouraged to adopt integrated skills approach in which a variety of language skills were practised along with the goal of fostering communicative competence. According to Kern, R. (1995), there is less teacher and more learner talk in computer classes, which leads to an independent learning phenomenon and makes the entire learning process learners-centered. Warschauer, Turbee, and Roberts (1996) are of the view that vision and hearing are the two dominant senses that media technology can provide to the students and present greater opportunities for learning linguistic inputs. Nagata (1997) believes that online learning devices facilitate the understanding of complicated concepts in grammar. Nagata (1999) considers technology as an important tool for teaching and learning all language skills in EFL classroom. He favors integration of technology in the entire English curriculum. Pope and Golub (2000) asserted that as students perform diverse tasks with the computer, they broaden their "repertoire of cognitive, metacognitive and effective learning". Warschauer (2000) accepted that EFL students could perform drills better with the help of computer. They could better understand the accentual patterns online and repeate together in the same way. This would enable them to produce correct accent and intonations. Sethi \& Newbill (2001) point out that grammatical instruction could be better presented using sounds, video clips, animations and feedback. Liu et al. (2002) recommend the use of multimedia authoring software that can help teachers create their own interactive activities. Morrison (2002) also endorsed the utility of these technological devices but he added that teachers' lack of technological experiences might hinder their ability to generate their own interactive grammar contents. Hence, the need for professional development of a teacher is prerequisite to enhance his/ her teaching competence.

Landerholm, et al. (2000) support the integration of language softwares in ESL curriculum because these softwares contain numerous exercises on grammar, vocabulary and audio and video clips to improve learners' pronunciation, language accuracy and word power. Kern, R and Warschauer, M. (2000) observed that broadband-related technologies have a unique significance, enabling learners to communicate with each other online and bringing native speakers into contact with non-native speakers and providing opportunities to develop intellectual, professional and language skills. According to Leask (2001), Computer Assisted language learning can be particularly effective due to the immediate feedback. According to Yang, S. C. (2001), technology has the potential to change learners' perception, nurture positive attitude towards learning of language skills and to "correct students' phonological realization". Brandl (2002) raised an important point about web-based learning. To him web-based learning provides learners with authentic reading resources. The EFL learners have online access to native speakers who could be seen and heard on You Tube on different pedagogical issues. Therefore, Brandl advocates full integration of technology in improving learners' reading skills. According to Battro, A.M. (2004), ELT practitioners can provide scaffolding in the overall language-learning objective through technological devices. Technology assists EFL learners' listening skills a great deal. Kruse (2004) is of the view that many video/audio resources and VoIP applications are effective solution to development of listening and speaking skills of L2 learners. Lacina (2005) also considered some of the authentic websites as viable resourses for teachers to teach various components of grammar and to encourage the EFL learners to do the quizzes available online. 
Dalvit, Murray, Mini, Terzoli \& Zhao (2005) acknowledge that language website are important source of information and language inputs, which support EFL learners to boloster their integrated language skills. They ae of the view language websites contain EFL learning materials in abundance which are pertinent to listening, speaking, reading, writing, vocabulary, grammar and pronunciation. LeLoup \& Ponterio, (2006), considers a huge online video pool a "priceless opportunities" to practice listening skills in an entertaining and "convenient environment". According to him, television/radio shows, news, documentaries, music videos and any videos have inherent potentials to ehhance learners' listening and speaking skills.

According to Beckett and Miller (2006), technology could be used for all sorts of specific language learning activities, such as oral practice, reading and writing skills development. Zhanghongling (2006) strongly supports the use of technology in teaching language skills. He is of the view that media technology does offer rich and authentic online resources which incorporate attractive and multiple audio and video materials. Jackson et al. (2006) in their study found that students who used the Internet more got higher scores and grades. Pitler, Hubbell, Kuhn, \& Malenoski (2007) pointed out that behavioral theory of learning could be better taught with technological devices through drill activities leading to the acquisition of accurate pronunciation of difficult English words. Research data also show that EFL learners easily understand and retain new words with technology. For example, Nakata (2006) investigated that repeated exposures to media technology has far-reaching effects on learning and retention of new vocabulary. Hulstijn \& Laufer (2001) advocated that the retention of unfamiliar vocabulary depends on learners' involvement in the use of technology. Plester et al. (2009) suggested that text messaging might improve students' reading and spelling abilities. Chapelle (2010: 66) considered CALL as an effective tool for language learning. He realized the role of interactive CD-ROMs, email, blogs, and Wikis in EFL / ESL contexts. Hattie (2009) affirmed that a highly significant attribute of these technologies is "visible learning". Baturay et al. (2010) also endorsed the idea that technology based instructions offer enriched multimedia grammar contents. According to Cetto (2010), technology expands the horizon of teaching and empowers learners with robust language skills and language use. Houcine (2011) also affirmed the effectiveness of Internet and hypermedia in English language teaching. He considered Internet a powerful resourse for both EFL learners and teachers. Motteram, Onat-Stelma and Slaouti, (2012) felt the huge impact of a wide range of technology on language learning. To them, technology-mediated language learning seems vital for the teaching of integrated language skills. Hosam (2012) considered TALL a better panacea for demotivated learners of English, because traditional method of teaching is very dreary and uninspiring. Traditional method of teaching makes learners passive recipient whereas TALL increase learners' enthusiasm for learning a great deal. With regard to grammar teaching and learning, many researchers strongly supported the implementation ogf technology in the teaching and learning of grammar. For example, Munir, Amelia, Issham \& Siti Nur Afiqah (2012) strongly supported the teaching of grammar via SMS, because he considers SMS a significant pedagogical tool for teaching grammar. Issham Ismail \& Rozhan M. Idrus (2009) are also of the view that learning grammar via technology such as computer, mobile/ SMS offers more fun to the learners and give them a unique excitement to learn grammar communicatively.

According to Solanki (2012) the use of authentic technological resourses is effective in teaching and learning English as a foreign language. It has an edge over traditional methodologies and revolutionizes the learner's dynamism for learning. Madhavaiah, G. et. al.( 2013) also validate that technology propels the entire learning process and invigorates EFL learners to learn language skills faster than before, because technology has multifaceted features to meet all the requirements of learners. Al-Subary (2013) conducted an intensive survey in Yemen about the integration of technology in teaching and learning and found that web-based teaching and learning serve as an important tool to enhance learners' performance in acquiring language skills. $\mathrm{He}$ is of the view that technology equips learners with skills necessary to flourish in professional career in the 21st century. Skyes (2013) believes that technology gives very enjoyable experience to both learners and teachers. And integration of educational technology into ELT classes will instill in learners substantial motivation for learning English as a foreign language. Digital games play a significant role in fostering language skills. According to Odera \& Ogott (2014:4), Internet capable technology assists collaboration and social networking which could provide a better link between teachers and parents. Teachers can customize and upload their own teaching materials in conformity with the level of the students and track the language activities and their progress online. The aforesaid research data manifest that the ELT teachers and applied linguists have always supported the integration of educational technology in language teaching, because they strongly believed that TALL had enough and multifaced potentials to improve learners' comprehensive language skills. As mentioned above, the ELT champions since 1960 have been advocating the integration of e-learning systems in English language classrooms and their pronouncements substantiate the hypothesis of the present study. However, the present study is unique in the sense that it delves deeper and fathoms the effectiveness of technology in teaching and learning of grammar, vocabulary, listening and speaking skills in Saudi context. The findings of the present study have been inferred on the basis of contrastive analysis between the performance of traditional group of EFL learners( control group) and technology assisted EFL learners (experimental group). Moreover, unlike the general opinion of earlier researchers, the present research is specific to Saudi EFL learners. It means the present study starts from the insightful findings of Saudi specific context but it could be implemented in general context also. The efficacy of technology in EFL classroom may have the same impact in other non-native English speaking countries as in Saudi Arabia. The present research is built around the following important hypotheses.

The present research is built around the following important hypothesis

\section{3 Hypothesis}

1. Online teaching and learning of grammar, vocabulary and listening / speaking skills are more effective than traditional methods 
2. The performance of technology assisted EFL learners in acquiring integrated language skills is better than that of traditional methods.

3. The performance of technology assisted EFL learners in pronunciation and communication skills is better than that of traditional methods.

\section{Materials and Methods}

The present research is based on the primary data as well as secondary data. The primary data were collected through three contrastive surveys conducted between traditional group (control group) and TALL group (experimental group) about listening/ speaking, vocabulary and grammar. The secondary data were derived from published sources.

\subsection{Primary Data}

The present study draws on how technology affects multisensory learning and how its enormous potentials assist EFL / ESL learners in listening/ speaking, vocabulary and grammar. To explore how technology increases learners' efficiency in the aforesaid language components, four tests were conducted. First and foremost a standard confirmation test corresponding to the Saudi EFL learners' linguistic efficiency in English was conducted on 100 Saudi EFL learners who are pursuing intensive English courses at King Abdulaziz University, KSA. The standard confirmation test was based on pronunciation, vocabulary and grammar. The respondents were given fifty questions to answer within two hours and the correct answer to each item received one point. There was no penalty for false responses. The confirmation test was conducted randomly to explore the homogeneity of the class. The homogeneity of the students was confirmed through statistical technique. The participants ranged in age from 20-25 were pursuing intensive English courses. The proficiency level of all the students was found almost homogenous in pronunciation, grammar and vocabulary. The responses of the female students aren't taken into account due to traditional hindrance. Therefore, the three major surveys were conducted merely on the male participants.

The second test was contrastive in nature. The same hundred students were divided in two groups: Group A represented traditional method (control group) for learning listening and speaking skills. Group B represented technology assisted learners of listening and speaking skills (experimental group). Listening and speaking skills were comprised on listening comprehension and pronunciation. The students were asked to listen to native speakers of English through CD ROMs and then to check the responses. The aim of this test was to explore what degree the students of both the groups are able understand the native speakers of English and to identify the authentic accentual patterns of English words. The second part of this was aimed at exploring which group is able to pronounce maximum number of given words correctly. Fifty English words were given to both groups to learn and pronounce them with proper accent. Both groups were given two week time to learn the correct pronunciation of the given words and take the final test of listening and speaking skills. The participants ranged in age from 18-25 were Saudi EFL learners who were pursuing intensive English courses. The samples of listening and speaking tests are given below:

Refer to appendix 1. Words for speaking / pronunciation test

Refer to appendix 2.Listening comprehension test

The third test was again contrastive in nature. Again the same hundred students were divided into two groups: Group A represented traditional method for learning vocabulary (control group) and Group B of TALL learners (experimental group). This test was based on matching words with pictures displayed online and choosing correct words from the multiple options. Fifty English words were given to both groups to learn: Group A with words- meanings but Group B with words-pictures and online translation. Both groups were given two week time to learn and take the final test. The participants ranged in age from 20-25 were Saudi EFL learners. The sample of final vocabulary test is given below:

Refer to appendix 3 sample of vocabulary test

The fourth test was based on the learning of grammar through traditional method and through technology. It was declared that after two weeks, there will be grammar test on indirect questions and active-passive. The same hundred students were divided into two groups: Group A represented traditional method ( control group) which encouraged students to learn the rules of grammar first and frame sentences according to grammar rules. On the other hand, Group B (experimental group)was asked to navigate some websites online which give lots of practice on the aforesaid grammatical topics. The sample of final test is given below:

Refer to appendix 4 grammar test

\subsection{Secondary Data}

Secondary data was collected from online published scientific research papers about technology assisted language learning and its huge impact in listening/ speaking, vocabulary and grammar learning. In the present research, in-depth analysis and empirical findings on hybrid learning systems were explored from the following authentic published sources: 1. Online resources include research papers on TALL published online. 2. Articles on TALL published in Saudi Daily English newspapers.3. Different magazines and research journals regarding the impact of TALL in learning integrated language skills.

\subsection{Data Collection Methods}

The data of the present research were collected through contrastive analysis. Hundred students of intensive English courses at King Abdulaziz University were divided into two groups: traditional group and TALL group. The aim was to explore the performance of both the groups in listening/ speaking, vocabulary and grammar. A large number of learning materials on listening/ speaking, vocabulary and different components of grammar were distributed to both the groups. The respondents were between 18-25 years old. The time for preparation was given two weeks. After two weeks, final test was conducted to investigate the performance of both the groups in listening/ speaking, vocabulary and grammar. 
the exact level of attainment and performance of both the groups. One hundred students of intensive English courses of King Abdulaziz University were divided into two groups: traditional group and TALL groups. The respondents were asked to check true and false responses in listening comprehension and to pronounce the given words with authentic accentual pattenrs. Finally, the scores of the participants were analyzed with figures and tables.

\section{Results/ Discussion}

The findings of the second survey in table.1 unveil the outstanding performance of the students of TALL group (experimental group) in listening comprehension and their ability to pronounce the given words with correct accentuation patterns. The students of TALL group performed very well. While taking the feedback from them, they frankly spoke that they outperformed their counterparts owing to their frequent exposure to native speakers of English online. By listening to the native speakers of English, they easily learned the authentic accentual patterns of English words. On the contrary, the performance of the students of traditional group was found relatively low, because they said that since they were neither exposed to native speakers of English and nor used to native accentual patterns, so they were unable to identify how words and phrases were spoken by native speakers of English. Therefore, it was inferred that the inability of the students of traditional groups to identify how words were pronounced by native speakers of English was responsible for their poor performance in listening and speaking skills. The experimental group of TALL took the fair advantage of technology and learned the correct pronunciation of given words online. They repeatedly listened to the authentic pronunciation of the given words online. By listening to native speakers regularly, they become well aware of how English vowel and consonants are pronounced. They observed the lip movement of native speakers and learned easily how they pronounce vowel and consonant sounds. The table below gives the actual statistical details of both the groups:

\begin{tabular}{|l|l|l|}
\hline Percentage of Marks & Traditional L/S & Technology Assisted L/S \\
\hline 0 to 10 & $0 \%$ & $0 \%$ \\
\hline 11 to 20 & $30 \%$ & $0 \%$ \\
\hline 21 to 30 & $10 \%$ & $0 \%$ \\
\hline 31 to 40 & $0 \%$ & $0 \%$ \\
\hline 41 to 50 & $20 \%$ & $0 \%$ \\
\hline 51 to 60 & $10 \%$ & $10 \%$ \\
\hline 61 to 70 & $20 \%$ & $15 \%$ \\
\hline 71 to 80 & $10 \%$ & $20 \%$ \\
\hline 81 to 90 & $0 \%$ & $30 \%$ \\
\hline 91 to 100 & $0 \%$ & $25 \%$ \\
\hline
\end{tabular}

Fig. 1. Traditional L/S Vs. technology Assisted L/S

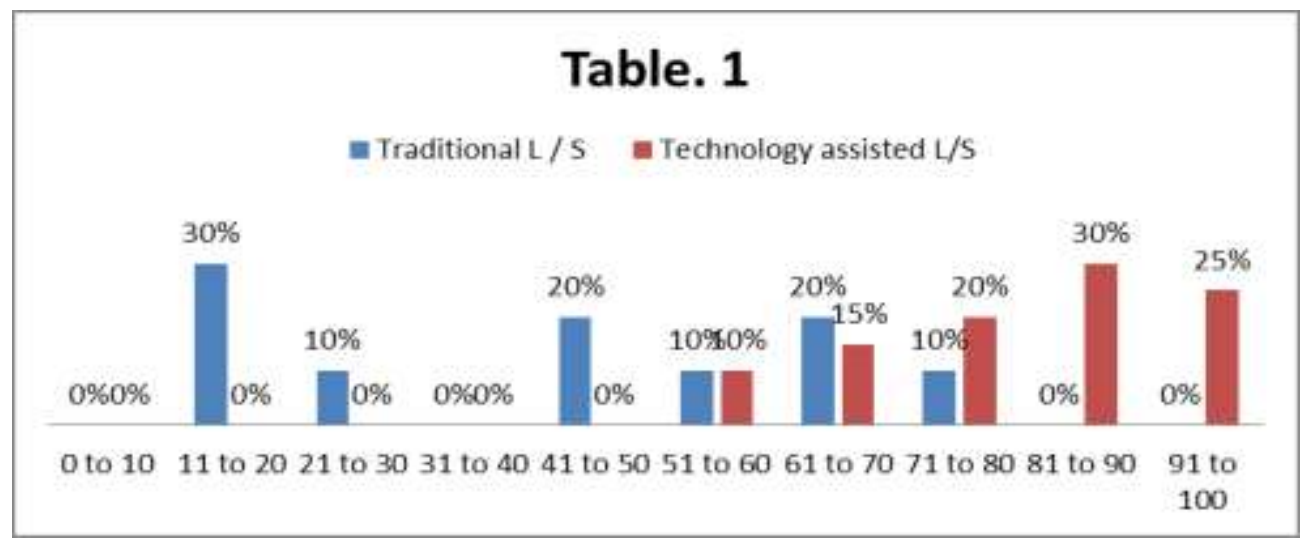

The findings of second test in table.2 illustrate a resounding difference between the attainment of traditional learners(control group) and TALL learners(experimental group) in listening and speaking skills. The learners of traditional approach performed very poorly in the final test whereas the learners of TALL approach performed very well, because while listening to native speakers online, they became used to the authentic accentuation and intonation patterns of English words and sentences. The students of traditional approach were least exposed to authentic pronunciation of native speakers on YouTube and online English dictionaries. Therefore, their performance in the final test was abysmally bad. None of the students of traditional approach obtained 80-100 \% marks in listening and speaking skills, because they were unable to understand the accentual pattern and hence declined to give correct responses and the correct pronunciation of given words. Only $10 \%$ students of traditional approach were able to give correct responses and produce $70 \%$ of given words accurately. The performance of just $20 \%$ students of this group went up to just $60 \%$ and the overall performance of the students of traditional approach was below the average. On the contrary, the performance of the students of TALL was unprecedented, because they consistently listened to the native speakers of English online. Consequently, they became familiar with the correct accentual patterns of English words and understood the native speakers online. They also practised well the given words online, repeated, and drilled accordingly. They reported that they observed the lip movement of the native speakers online and understood very well the manner and 
place of articulation. Consequently $25 \%$ students of TALL group obtained $100 \%$ score in listening and speaking tests. $30 \%$ students got $90 \%$ marks and $20 \%$ students obtained $80 \%$ marks. None of the students of TALL group obtained below $60 \%$ marks, whereas a large number of students of traditional approach obtained even below $20 \%$ of marks. It can be inferred that the performance of the students of TALL group was found far better than that of the students of traditional approach in listening comprehension and speaking skills, because they had an edge over their counterparts owing to their frequent exposure to the correct accentuation and intonation patterns used by the native speakers of English online.

It is also advisable to discuss about the inherent problematic areas of pronunciation that the students of traditional group of this study or the students of entire Arab world in general are encountered. The native speakers of Arabic have specific problem with /p/ phoneme. They are unable to distinguish between /p/ and /b/ English phonemes. Instead of /'pepsi/, they pronounce /'bebsi/, /'pi:p(ə)1/ becomes /'bi:p(ə)l/, / pen/ becomes /ben/, /'perpə/ becomes /'berbə/, /pa:k/ becomes /ba:k/, /pa'li:s/ becomes /ba'li:s/ and so forth. This problem occurs because /p/ phoneme doesn't exist in Arabic language. It was found that the students of TALL approach overcame this problem because they observed the manner and place of articulation while listening to native speakers online. They found that the native speakers put their upper lip on their lover lip while pronouncing $/ \mathrm{p} /$ sound. They practised exactly the same way and hence were able to pronounce it with absolute accuracy.

Pronunciation of "The" is also a common problem for Arabs. Instead of /ðə/, they pronounce / z /. Hence, /ðॄ:/ becomes

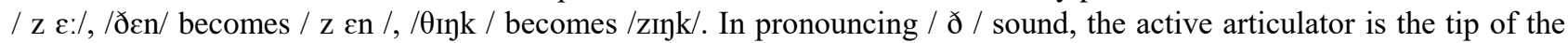
tongue, which touches upper teeth which is a passive articulator. On the contrary, in pronouncing / $\mathrm{z} /$ sound, the active articulator is the blade of the tongue, which touches alveolar ridge which is passive articulator. The students of TALL approach learned well how to pronounce $/ ð /$ sound by frequently listening to native speakers online. It is also worth mentioning here that English is a non-phonetic language, because the words aren't spelled the way they sound. This causes a big problem to the non-native speakers of English who have never been exposed to the native speakers or who have never lived for few years in native English speaking countries. In addition, English spelling and pronunciation have many irregularities and inconsistencies, as a result, the pronunciation of some words go beyond the expectation of the non-native speakers of English. At this point of time, overgeneralization and the influence of mother tongue go hand in hand in pronouncing some non-phonetic words which are quite different from the authentic native speakers' pronunciation. For example, the pronunciation of these words: through, cough, plough, thorough, chemistry, chivalry, chair, are ambiguous for non-native speakers of English who come across these words first time. So, TALL will be a great help for them in learning the correct pronunciation of English words. They can easily find the correct pronunciation of non-phonetic words online.

The findings of earlier research data substantiate my research findings about the impact of TALL in listening and speaking skills. For example, Labayen et. al. (2006) also found technology highly effective in improving EFL learners' listening and speaking skills. According to him, Internet and multimedia tools that contain sounds and images make a big difference in the process of enhancing EFL learners' listening and speaking skills. Volle (2005) also investigated in her research that EFL learners who used Skype, MSN Messenger, GoogleTalk and similar VoIP applications found an opportunity to connect a native speaker on the internet and converse with them for free. This improved tremendously EFL learners' listening and speaking skills. Ilter, (2009), Wu, Yen and Marek (2011) explored in their studies the unprecented impact of technology in increasing learners' motivation for listening to online audio and video resources in order to improve their listening skills. They also found that while listening to online audio and video resources, the ESL learners were found to ward off their hesitation and shyness and try to speak English. Jahan N. (2011) conducted his study on EFL students in Benladesh and found extraordinary impact of technology in improving learners' pronunciation. He concluded that while listening to the native speakers of English online, the EFL learners became familiar with the proper accent and intonation patterns. Consequently, they improved their pronunciation and were able to speak with correct accentual patterns.

The result of the third survey in table. 2. Shows that the students of TALL groups also performed very well in vocabulary learning. They opined that the conceptual meaning of English words became crystal clear when they used Google translation and sometimes the images of the given words. In fact, online learning of vocabulary lays its huge impact on learners' intrinsic motivation for learning vocabulary with bilingual approach, because they better understand the concept of English words with images and substitute meaning $\mathrm{s}$ in their mother tongue.

Fig.2 Traditional Vocab learning Vs. Technology Assisted Vocab Learning

\begin{tabular}{|l|l|l|}
\hline Percentage of Marks & Traditional G Learning & Technology Assisted G Learning \\
\hline 0 to 10 & $0 \%$ & $0 \%$ \\
\hline 11 to 20 & $20 \%$ & $0 \%$ \\
\hline 21 to 30 & $10 \%$ & $0 \%$ \\
\hline 31 to 40 & $10 \%$ & $0 \%$ \\
\hline 41 to 50 & $20 \%$ & $5 \%$ \\
\hline 51 to 60 & $10 \%$ & $5 \%$ \\
\hline 61 to 70 & $10 \%$ & $15 \%$ \\
\hline 71 to 80 & $10 \%$ & $20 \%$ \\
\hline 81 to 90 & $5 \%$ & $20 \%$ \\
\hline 91 to 100 & $5 \%$ & $35 \%$ \\
\hline
\end{tabular}

Fig: 2. Traditional Vocab learning Vs. Technology Assisted Vocab Learning 


\section{Table.2}

Traditional vocabulary learning = Technology assisted vocabulary learning

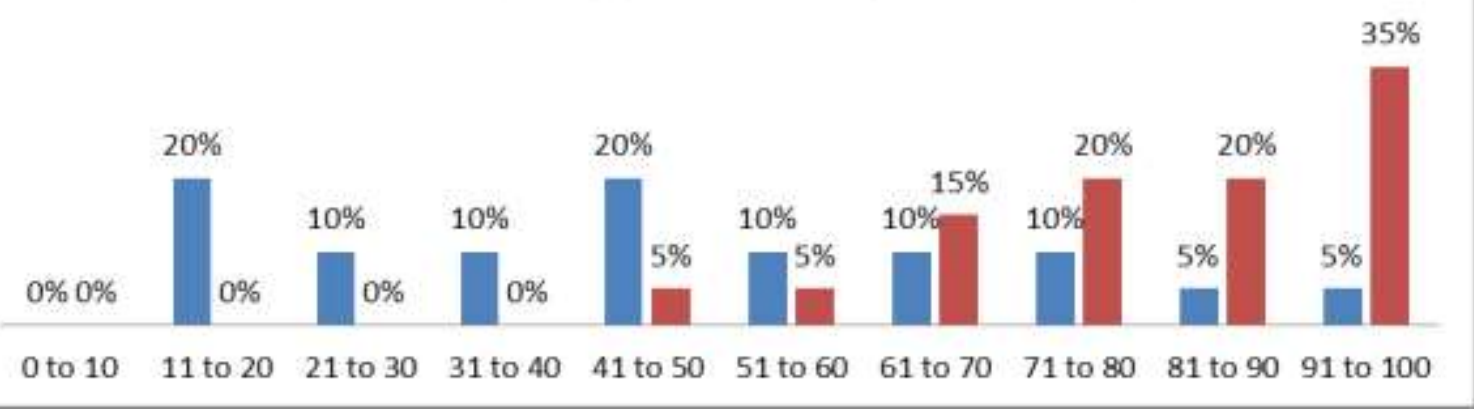

The findings of table 2 demonstrate a significant difference between the performance of Group A which represents traditional vocabulary learning (control group) and Group B which represents technology assisted vocabulary learning (experimental group). The main aim of this test was to explore if the score of both the contrastive experimental groups in vocabulary learning was homogenous or any significant difference between them was prominently found. The performance of Group B is self-explanatory because it performed remarkably well. $35 \%$ students of Group B obtained $100 \%$ marks and none of the students of Group B obtained less than 50\% marks. On the contrary, only 5\% students of Group A obtained 100\% marks and again only $5 \%$ students of traditional group scored just $80 \%$ marks. In contrast, $40 \%$ students of Group B got less than $40 \%$ marks. It can be inferred that the maximum number of the students of group B scored 100\% marks. The second remarkable finding was that the score of the students of group B began from 50\% of marks onwards whereas the score of the group A began from $20 \%$ of marks onwards. It could also be claimed that a large number of students of group A scored very poorly that was between $11 \%-50 \%$ of marks only. On the opposite, only $5 \%$ students of group B scored so poorly because their scores started from $50 \%$ onwards and it went up to $100 \%$ of marks in vocabulary learning. On deeper analysis, it was found that the conceptual meaning of difficult words is well understood through bilingual approach. In fact, comprehension and retention of new words occurs more if vocabulary is learned through online translation and visual prompts. For example, it was already announced that vocabulary test will be conducted on fruits, vegetables and dry fruits. The students of Group B learned vocabulary on the given topics through online Google translation and visual images. Google translation plays a significant role in teaching difficult English words to EFL/ ESL learners. The conceptual meaning of difficult words becomes crystal clear by adopting online bilingual approach and showing visual prompts. This resulted in unprecedented attainment owing to their frequent exposure to online translation and visual images.

The EFL learners' score in this survey shows that technology can help EFL learners master both "active and passive vocabualy". By active vocabualy, Milton (2009) means the words that a student is able to produce in speaking and writing and by passive vocabulary, he means the words that a student is able to understand in speaking and writing.The empirical studies conducted earlier validitate the research findings of the present study regarding the profound impact of technology in learning vocabulary. For example, Thornbury (2002) asserts that learners using TALL learn vocabulary effectively because they associate words with pictures, use flash cards to enhance word-meaning and translate difficult words in LI equivalents. Chih-Cheng Lin, et, al. (2014) found the similar result in their contrastive studies between experimental group and control group on the effect of technology in vocabulary learning at National Taiwan Normal University, Taiwan. Their findings manifest that the students of TALL (experimental group) outscored the learners of traditional group (control group), because the rention power of TALL learners were higher than that of traditional learners. According to Tabar \& Khodareza (2012), Computer assisted vocabulary learningis is the most effective tool for vocabulary learning, because it contains both sound and images which improve learners' ability to understand the conceptual meaning of difficult words and to pronounce the words correctly.

\begin{tabular}{|l|l|l|}
\hline $\begin{array}{l}\text { Percentage of } \\
\text { Marks }\end{array}$ & Traditional G Learning & Technology Assisted G Learning \\
\hline 0 to 10 & $10 \%$ & $0 \%$ \\
\hline 11 to 20 & $10 \%$ & $0 \%$ \\
\hline 21 to 30 & $10 \%$ & $0 \%$ \\
\hline 31 to 40 & $10 \%$ & $0 \%$ \\
\hline 41 to 50 & $20 \%$ & $5 \%$ \\
\hline 51 to 60 & $10 \%$ & $5 \%$ \\
\hline 61 to 70 & $10 \%$ & $10 \%$ \\
\hline 71 to 80 & $10 \%$ & $15 \%$ \\
\hline 81 to 90 & $5 \%$ & $35 \%$ \\
\hline 91 to 100 & $5 \%$ & $30 \%$ \\
\hline
\end{tabular}

Fig. 3. Traditional Grammar learning Vs. Technology Assisted Grammar Learning 


\section{Table.3}

- Traditional G Learning a Technology assisted G learning

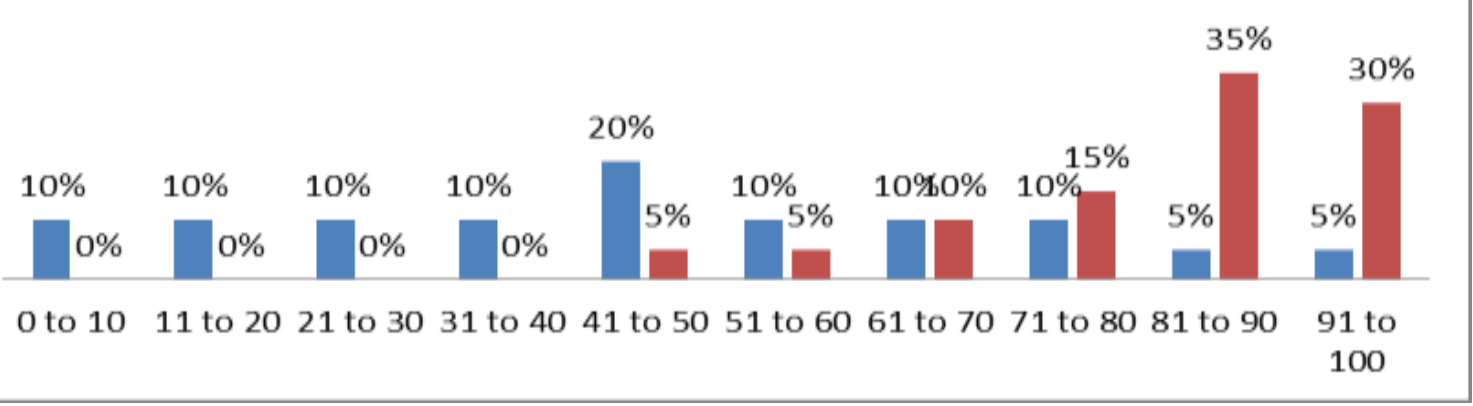

The main findings of table.3 suggest that grammar instruction through traditional method was perceived very boring. Traditional method for teaching grammar begins with the assumption that the learner should first learn the grammar rules, which they can use later in producing the sentences. Teaching about the rules is very boring for the learners. That is why the performance of the students of tradition group (control group) was found unsatisfactory. Only 5\% of the students of traditional method obtained $100 \%$ and another 5\% students scored $90 \%$ marks. On the contrary, $30 \%$ students of TALL group (experimental group) obtained 100\% marks and 35\% students scored $90 \%$ marks. None of the students from TALL group obtained less than $50 \%$ marks where as 50\% students of traditional group obtained less than $50 \%$ marks. The findings of the present study reveal that the performance of TALL students in grammar is outstanding and consequential, because they foud online learning of grammar more communicative and exciting. On thorough analysis, it was explored that traditional method for learning grammar was less communicative and least conducive to learning skills, because more focus was laid on rules rather than how to use rules to make creative and communicative sentences. Conversely, the students of TALL group experienced online learning grammar as a profound tool to communicate accurately and effectively that prevents them from heinous misunderstandings. In the postmodern era, some schools either have completely ignored grammar teaching or complicated the grammar rules, but the fact of the matter is that teaching and learning of grammar can never be ignored because it is the skeleton of the language. Endorsing the significance of grammar, David Wilkins (2012) says "Without grammar little can be conveyed; without lexis nothing can be conveyed."

Teaching grammar through traditional method is dreary where both students and teachers cringe, but learning grammar online is very exciting because numerous exciting ways to teach grammar are available online: YouTube can be used as a model to teach grammar and to motivate EFL/ ESL learners a great deal. The EFL learners can explore how ELT professionals use different communicative methodologies online to facilitate learners to learn grammar components more effectively and more creatively. For example, board racing technique found on YouTube in abundance is a fun way to teach English grammar communicatively. The students are split into two groups and the students of each group are asked to begin and end writing the grammatical answers on the board within specified time. The group which is able to write maximum number of correct responses is declared winner. This method of grammar teaching encourages and engages each student to perform actively and contribute his bit to the given task. This also builds up an exciting environment for grammar learning and producing meaningful sentences. Another exciting technique "Pictionary"game, found on YouTube is a great team game and pragmatic guideline for ELT teachers to teach grammar in an exciting manner. In this game, the learners are encouraged to revise vocabulary in a fun and interactive way. Timeline practice is also useful to teach Simple Past. The students may be asked to generate their personalized timelines and write the numerous events that took place in their lives in the past. This is the best way to teach Simple Past where students are asked to use the verb in simple past. Any grammar teaching method that is engaging and participatory will be more productive and exciting for the learners.

The experimental surveys conducted earlier regarding the impact of technology in grammar teaching and learning, confirm the findings of the present research. For example, Hall, C. (1998) supported the use of technology for grammar teaching. He was of the view that technology contains abundance of videos for teaching grammar effectively. Saadiyah (2013) in her study conducted in one of the Malaysian universities explored the effectiveness of technology in grammar learning. To her, technology plays an important role in motivating learners to produce grammatically correct sentences. Mariam \& Woollard (2010) conducted a survey on using mobile technology in teaching grammar in secondary schools in Malaysia and found that Intelligent Mobile Learning (i-MoL) Tool for Grammar Learning supports grammar learning through "cross-platform user interface" a great deal. Gulden Ilin, Ozge Kutlu and Abdurrahman Kutluay (2012) explored in their study that videos for grammar teaching motivated learners to learn grammatical components communicatively and led them to the reinforcement of what they learned online. Learners' performance was found better in learning and using grammar correctly in every given situation.

All the surveys conducted in this study reveal that modern technological devices with robust Internet connection have profound effect in the teaching and learning of vocabulary, grammar and listening/ speaking skills. The students of TALL group (experimental group) have outscored the learners of traditional groups. There are various reasons that are responsible for raising the impact of technology in EFL learning. First, this is undoubtedly true that modern technology engages learners' enthusiastic participation and hence turns the whole learning process very exciting and learners 
centered. Secondly, TALL learners can make the best use of their leisure hours, if connectivity is available, to explore plenty of online-learning materials and improve their proficiency in English. Therefore, robust connectivity is very vital to entrench EFL learners' progress and scale up their language competence and performance. Thirdly, TALL exposes EFL learners to English as a living language providing them with ample opportunities to practise target language through the use of authentic texts, authentic grammar and authentic accentual patterns. In addition, many authentic case studies manifest that TALL makes an increasingly significant contribution to ELT because both teaching and learning transcend the four -walled -classrooms. The proponents of TALL are fully convinced that it is important to embed technology in teaching EFL curricula to keep learners fully engaged and hooked to their language activities.

Technology has changed both: the role of a student and the role of a teacher. Instead of just being a passive recipient in the class the students have to engage themselves actively in problem solving, communication, collaboration, and knowledge creation and to act as knowledge manager. Instead of just relying on teachers for everything, they have to grow as independent learners and act as the master of their own time. They are supposed to improve their skills by using online authentic resources such as YouTube, email, Twitter, Discussion Forums, Skype, WhatsApp, iPods, tablets and ereaders. These technological resources with Internet connectivity can provide authentic communication opportunities to EFL learners beyond the EFL classrooms, because they can use them anytime and anywhere to improve their interactive reading experience. This interactive reading can expose EFL learners to different syntactical structures and can expand wide range of vocabulary. In order to improve listening skill, EFL learners have to make the best use of YouTube, simple audio materials and audiobooks. In fact, extensive listening is prerequisite to improve both listening comprehension and speaking skills. Listening to the native speakers of English online and reading text at the same time is a great way to improve listening comprehension and accentual patterns of English words. Podcasts are also important tools to improve listening skills. Here are some popular podcasts the EFL learners can try: Listen to English by Peter Carter, Elementary Podcasts by the British Council and Luke's English Podcast.

There is always a misconception that modern technological devices can replace teachers and make them less necessary for the students. In fact, teacher's role in the modern technology-led pedagogical setup is more challenging than before. The modern EFL teachers aren't just supposed to mesmerise EFL learners with their lecturing potential but they are also expected to facilitate learners and engage them in the whole learning process. Their entire focus should be on how to make learning more effective. In modern technological era, the concept of pedagogy has completely changed. The modern EFL teachers have to evolve their teaching to fit with the latest gadgets. They have to be competent in using WhatsApp, Twitter, email, Discussion Forums, Skype and other tools, which can provide authentic communication opportunities to the learners. They have to cope with the paradigm shift, so called, from traditional learning dubbed as teacher- centered approach to student-entered learning; (SCL) which puts students at the heart of the learning process. The EFL teachers have to encourage learners' full potential to embark on online authentic resources to stay independent learner rather than to be considered just as empty vessel or passive receptor blindly relying on teachers as full authority. The EFl teachers should introduce participatory approach, where students can be actively engaged in the whole blended learning process. They have to facilitate students to tackle learning problems based on their own capabilities with the help of modern technological devices which can enrich EFL learners' learning experience and empower them with the wide range of integrated language skills. They are expected to play the role of an instructional designer, facilitator, trainer, mentoring and assessment specialist where they have to customize teaching materials, prepare effective summative assessment policies and integrate technology in EFL classrooms in order to facilitate learners to accomplish unique language learning tasks. Collaborative teaching which focuses on informal sharing teaching experience with colleagues and team teaching is becoming very common in modern pedagogical scenario. Here teachers are supposed to share their innovative and practical pedagogical experiences with their colleagues in order to make the whole learning process more informative and effective. The new roles of modern EFL teachers, in tandem with the new student roles, will make teaching and learning more effective.

There is a big challenge for the teachers and the parents as well in modern digital age. They have to think about how to encourage learners to make the best use of technological gadgets. Some researchers point out that it becomes worst when students become addicted to smartphones. They feel nomophobia when they are prohibited to use mobiles in the classrooms. In fact, learners' frenzied addiction to smartphones distracts learners' concentration and engagement with learning. The teacher and parents can obliterate nasty side effects of smartphones on learners if they deal with students tactfully.

\section{Conclusions}

The empirical surveys conducted in this study speak volumes of an inimitable impact of integration of modern educational technologies in English language teaching and learning. It is evident from the findings of this study and the earlier research data as well that tech-savvy learners embraced online or digital games-based learning and outperformed the students of traditional based learning. The findings reveal a significant gap between the attainment of online and traditional learners in pronunciation, grammar and vocabulary. $25 \%$ online learners obtained 100 per cent score in listening and speaking, and 30\% of them obtained $90 \%$ accuracy in pronunciation. On the contrary, none of the traditional learners obtained 80-100 \% marks in listening and speaking skills. It was found that when online learners listened to the native speakers of English, they found the given words easier to pronounce. In fact, they became familiar with the accentual patterns of English words and were able to understand the native speakers of English online. Consequently, they achieved high score in listening comprehension and learned perfectly the accentual patterns of the given words and enjoyed the whole learning process while listening to native speakers of English. Therefore, it could be inferred that listening to native speakers on $\mathrm{TV}$, radio, $\mathrm{BBC}$, chat forums and on Internet is consequential to online learners' high performance in pronunciation. A significant difference was also found in vocabulary learning. $75 \%$ online 
learners obtained $80-100 \%$ marks in vocabulary, whereas only $20 \%$ students got $80-100 \%$ marks. The online learners of vocabulary produced better result than traditional learners. The online learners not only learned the words but they were also found competent enough to use the words in their day-to-day conversation. With regard to grammar learning, the performance of online learners was found outstanding. 65\% online learners scored 90-100 \% marks in grammar whereas only $10 \%$ traditional learners reached that attainment. The online learners of grammar navigated various websites where online grammar teachers were found more efficient in explaining various components of grammar on YouTube. It means they harnessed well the potential of e-learning and learned grammar more competently and effectively.

Limitations

The present study has certain limitations with regard to the statistical surveys. The surveys of this study were conducted only on Saudi male students. It is possible that Saudi female students' performance speaks another story and their performance and competence through online learning might be completely other way round. Based on this research, other researchers can conduct intensive language surveys on Saudi female intensive learners of English to obtain more pragmatic result.

\section{Acknowledgements}

I'm indebted to Mr. Abu Bakar, Islam Al Murabit, Mr. Asif, Mubeen Raza Khan, Dr. Asif, Dr. Munir, Dr.Zaid, and Dr. Fahad and to all those students of Saudi universities who participated in surveys conducted in this research. Last but not the least; I owe my thanks to JCC fraternity and KAU friends for their benign support.

\section{References}

Al-Subary A. A. (2013). Technology in teaching and learning in the republic of Yemen. Article Abstract. Retrieved from http://goo.gl/rXCj9k

Beckett, G. H. \& Miller, P. C. (2006). Project Based Second and Foreign Language Learning: Past, Present and Future. USA: Information Age Publishing.

Battro, A.M. (2004). Digital skills, globalization and education, in Surez-Orozco, M and QinHilliard, D Globalization: Culture and Education in the New Millennium. University of California Press.

Baturay, M. H., Daloglu, A., \& Yildirim, S. (2010). Language Practice with Multimedia Supported Web-Based Grammar Revision Material. ReCALL, 22(3), 313-331.

Brandl, Klaus. (2002). "Integrating Internet- Based Reading Materials Into The Foreign Language Curriculum: From Teacher- To- Student- Centered Approaches." Language Learning and Technology, 6(3), 87- 107. Retrieved from: http://goo.gl/QW0S4E

Chapelle, C. A. (2010). The spread of computer-assisted language learning. Language Teaching, 43(01), 66-74. doi: doi:10.1017/S0261444809005850

Cetto. M. (2010). Technology and second language teaching. Brujula, 8, 119-121.

Chih-Cheng Lin, Hsien-Sheng Hsiao and Hsin-jung Chan. (2014). Learning English vocabulary collaboratively in a technology-supported classroom. The Turkish Online Journal of Educational Technology - January 2014, volume 13 issue 1

Dalvit, L., Murray, S., Mini, B., Terzoli, A., \& Zhao, X. (2005). Computers and african languages in education: An ICT tool for the promotion of multilingualism at a south African university. Perspectives in Education, 23(4), 123- 131 David Wilkins. (2012). Language Moments, ELT Ideas and Resources. Retrieved from https://languagemoments.com/2012/10/11/grammarphobe.

Gulden IIin, Ozge Kutlu and Abdurrahman Kutluay. (2012). An action research: Using videos for teaching grammar in an ESP class. Procedia - Social and Behavioral Sciences, 70(2013) 272 - 28.

Hall, C. (1998). Overcoming the grammar deficit: The role of Information Technology in teaching German grammar to undergraduates. The Canadian Modern Language Review/La Revue canadienne des langues vivantes, 55(1), 41-60.

Houcine.S. (2011). The effects of ICT on learning/teaching in a foreign language. ICT for Language Learning, 4th

Edition. International Conference. Retrieved from conference.pixel-online.net/ICT4LL2011/

Hosam, A. (2012). Instructional Strategies for Teaching Reading: A Training Program for In-service English Language Teachers in Taiz City, Yemen. Retrieved from: http://goo.gl/45zkHj

Hulstijn, J., \& Laufer, B. (2001). Some empirical evidence for the involvement load hypothesis in vocabulary acquisition. Language Learning, 51(3), 539-558.

Ilter, B. G. (2009). Effect of Technology on motivation in EFL classrooms . Turkish Online Journal of Distance Education, 64(10).

Issham Ismail \& Rozhan M. Idrus. (2009). Development of SMS mobile technology for m-learning for distance learners. International Journal of Interactive Mobile Technologies (iJIM), 3, 55-57.

Jackson, L.A.,Eye, A.V. Biocca, F.A., Barbatsis, G., Zhao., Zhao, Y. and Fitzgerald, H.E. (2006) . Does home internet use influence the academic performance of low-income children ? British Journal of Development Psychology, 42 (3), 1-7.

Jahan N (2011). Teaching and learning pronunciation in ESL/EFL classes of Bangladesh. Journal of Education and Practice 2(3) 36-45.

John Hattie. (2008). Visible Learning: A Synthesis of Over 800 Meta-Analyses Relating to Achievement. published by Routledge; 1st Edition, Amazon.com.

Kern, R.(1995). Restructuring classroom interaction with networked computers: Effects on quantity and quality of 
language production. Modern Language Journal, 79(4), 457-476.

Kern, R and Warschauer, M. (2000). Network-based language teaching: concepts and practice. Cambridge: Cambridge University Press.

Kruse, K.. (2004). Using the Web for Learning: Advantages and Disadvantages, Retrieved May 14, 2007, from http://www.e-learningguru.com/articles/art1_9.htm

Kruse, K. (2004). Using the Web for Learning: Advantages and Disadvantages, Retrieved May 14, 2007, from http://www.e-learningguru.com/articles/art1_9.htm

Labayen, MJ., Estopanian, L., Olmos M. (2006). Speaking \& the Internet: an unlikely match?, p.9, Retrieved March 12, 2007, from www.developingteachers.com.

Lacina, J. (2005). Grammar Instruction and Technology. Childhood Education, 81(4), 247-249.

Landerholm, E.; Karr, J. \& Mushi, S. (2000). A Collaborative Approach to Family Literacy Evaluation Strategies. Early Child Development and Care, 162, 65-79.

Leask, M. (2001). Issues in Teaching Using ICT . London: Routledge.

Liu, M., Moore, Z., Graham, L., \& Lee, S. (2002). A look at the research on computer-based technology use in second language learning: A review of the literature from 1990-2000. Journal of Research on Technology in Education, 34(3), 250-273.

LeLoup, JW., Ponterio, R. (2007). Listening: You've Got To Be Carefully Taught, Language Learning \& Technology Journal, retireved May 14, 2007, from http://www.llt.msu.edu/vol11num1/net

Mariam Mohamad, \& Woollard, J. (2010). Bringing change in secondary schools: Can mobile learning via mobile phones be implemented in Malaysia? Paper presented at the 4th International Malaysian Educational Technology Convention, Kuala Lumpur, Malaysia.

Madhavaiah G., Nagaraju Ch. \& Peter S. (2013). Importance of Technology in Teaching and Learning English Language. International Journal of Scientific Research and Reviews, 2, 3, p. 146-154. Retrieved from: http://goo.gl/yGGTHP

Milton, J. (2009). Measuring Second Language Vocabulary Acquisition. Buffalo: Multiligual Matters.

Meskill C. \& Rangelova K.. (1995). "US language through literature: a transatlantic research project". In Warschauer M. (ed.) Virtual connections: online activities and projects for networking language learners, Honolulu, HI: University of Hawai'i Second Language Teaching and Curriculum Center.

Morrison, S., Languages, E. C. o., \& Linguistics, W. D. C. (2002). Interactive Language Learning on the Web. ERIC Digest.

Motteram, G, Slaouti, D and Onat-Stelma, Z. (2013). Second language teacher education for CALL: An alignment of theory and practice', in Thomas, M, Reinders, H and Warschauer, M (2013) Contemporary Computer-Assisted Language Learning. UK: Bloomsbury Academic.

Munir, S., Amelia, A., Issham I., \& Siti Nur Afiqah Z. (2012).The feasibility of teaching grammar via SMS. SPECTRUM Studies in Language, Literature \& Interpretation, 9

Nagata, N. (1997). The Effectiveness of Computer-Assisted Metalinguistic Instruction: A Case Study in Japanese. Foreign Language Annals, 30(2), 187-200. doi: 10.1111/j.1944-9720.1997.tb02341.x

Nagata, N. (1999). The effectiveness of computer-assisted interactive Glosses. Foreign Language Annals, 32(4),469479. Retrieved from: http://goo.gl/OYPbx2

Nakata, T. (2006). Implementing optimal spaced learning for English vocabulary learning: Towards improvement of the low-first method derived from the reactivation theory. The JALT CALL Journal, 2(2), 3-18.

Odera, F. \& Ogott, G. (2014). Use of Technological Resources in the Acquisition of Language skills in Early Childhood Development and Education programmes in Gem Sub-County, Kenya. International Journal of Academic Research in Progressive Education and Development. 3(4), 1-13.

Pitler, H., Hubbell, E., Kuhn, M., \& Malenoski, K. (2007). Using technology with classroom instruction that works. Alexandria, VA: ASCD.

Pope, C., \& Golub, J. (2000). Preparing tomorrow's English language arts teachers today: Principles and practices for infusing technology. Contemporary Issues in Technology an Teacher Education [Online serial], 1(1). Retrieved March 31, 2004, from http://www.citejournal.org/vol1/iss1/currentissues/english/article1.htm

Saadiyah Darus,(2013). The current situation and issues of the teaching of English in Malaysia. Retrieved from http://r-cube.ritsumei.ac.jp/bitstream/10367/4130/1/LCS_22_1pp19-27_DARUS.pdf

Sethi, P. S., \& Newbill, P. L. (2001). Infusing Interactive, Multimedia CD-ROM Technology into the First-Year College-Level Geology Curriculum: Recent Examples from Radford University, United States.

Sykes. M. (2013). "Just" Playing Games? A Look at the Use of Digital Games for Language Learning. SpecialFocus on Technology. Retrieved from

www.actfl.org/sites/default/files/pdfs/TLE_pdf/TLE_Oct13_Article.pdf

Skinner, B.F. (1953). Science and Human Behavior. New York: Macmillan.

Solanki D.S. (2012). Use of Technology in English Language Teaching and Learning. International Conference on Language, 26 Medias and Culture IPEDR vol.33 Press, Singapore. Retrieved in Dec. 2013 from: https://www.google.com.(ERIC Document Reproduction Service. No: ED511174)

Tabar1, H. and Khodareza, M. (2012). The effect of using multimedia on vocabulary learning of pre-intermediate and intermediate Iranian EFL learners. Journal of Basic and AppliedResearch,2, 12, pp. 12879-12891

Thornbury, S.(2002). How to teach vocabulary. London: Longman. 
Volle, L. (2005). Analyzing Oral Skills ?n Voice E-mail and Online Interviews, Language Learning \& Technology Journal, Retrieved March 5th, 2007, from: http://llt.msu.edu/vol9num3/volle/

Warschauer, M. \& Meskill, C. (2000). Technology and second language learning. In J.Rosenthal (Ed.), Handbook of undergraduate second language education (pp. 303-318).Mahwah, New Jersey: Lawrence Erlbaum

Warschauer, M. (2003). Demystifying the digital divide. Scientific American, 289/August: 42-47.

Warschauer, M., Turbee, L., \& Roberts, B. (1996). Computer learning networks and student empowerment. System, 24(1), 1-14.

Wu, W.-C., Yen, L. L., \& Marek, M. (2011). Using online EFL interaction to increase confidence motivation and ability. Educational Technology Society, 14(3), 118-129.

Yang, S. C. (2001). Language learning on the World Wide Web: An investigation of EFL learners' attitudes and Perceptions. Journal of Educational Computing Research, 24(2), 155-181.

Zhanghongling .(2006). The development tendency of the modern foreign language teaching and the computer assisted instruction. Computer- Assisted Foreign Language Education, 3.

\section{Appendixes}

\section{Listening Test}

Student Name: Student ID Group

Appendix 1. Words for speaking / pronunciation test

\begin{tabular}{|l|l|l|l|l|l|l|l|}
\hline Pepsi & There & Jameel & through & scratch & Chair & social & lamb \\
\hline pensive & Thirsty & Jamaican & cough & match & Chemistry & knee & thumb \\
\hline people & Theatre & Jam-packed & plough & listen & Chivalry & knife & comb \\
\hline paper & then & janitor & Thorough & chef & sure & know & doubt \\
\hline pen & theory & Japanese & mortgage & cheque & issue & knob & plumber \\
\hline period & Think & jargon & butcher & character & sugar & debt & tomb \\
\hline & & & & & & & \\
\hline
\end{tabular}

Appendix 2.Listening comprehension test

Listen to an interview with Jeri, a fashion model. Answer the questions.(--_-_/5)

1- Where did she grow up?

a- $\square$ Washington, DC

b- $\square$ Brighton, England

2- What did she want to do when she grew up?

a- $\square$ She wanted to be a doctor or a writer.

b- $\square$ She wanted to be an engineer.

3- Did she have a hoppy?

a- $\square$ Yes, she used to play football.

b- $\square$ No, she did not have a hoppy.

4- Did she have a favorite game?

a- $\square$ Yes, her favorite game was chess

b- $\square$ Yes, her favorite game was "hide and seek".

5- What was her favorite place?

a. Brighton, England

b. Dubai, UAE. c- 口 Paris, France

d- $\square$ Jeddah, Saudi Arabia

c- $\square$ She wanted to be an English teacher.

d- $\square$ She wanted to be a fashion model.

c- 口 Yes, she used to paint.

d- $\square$ Yes, she used to play video games.

c- $\square$ Yes, her favorite game was basketball.

d- $\square$ No, she did not have a favorite game.

Listen to three people talk about things they wish they could change. Check $(\curvearrowleft)$ the topic each person is talking about. (---/3)

$\square$ leisure time

口 skills

$\square$ opportunities c. $\square$ A summer camp in Ireland

d. $\square$ A winter camp in South Africa

Listen to Judy, Paul, and Brenda describing their summer planes. What is each person going to do and what is the reason for each person's choice? (----/6)

\begin{tabular}{|l|l|l|l|}
\hline & Person & Summer Plans & Reason \\
\hline 1 & Judy & & \\
\hline 2 & Paul & & \\
\hline 3 & Brenda & & \\
\hline
\end{tabular}


Appendix. 3 sample of vocabulary test

Match the following words with correct images. ( $-\ldots$

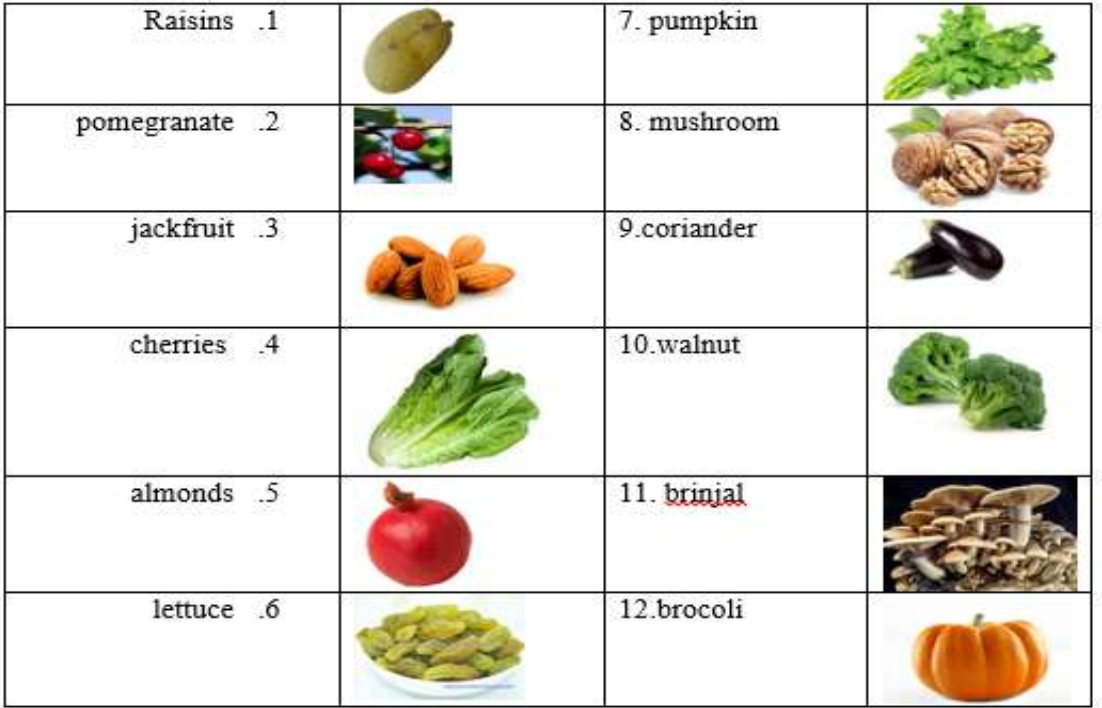

Choose the correct words from the brackets.

/5 Marks)

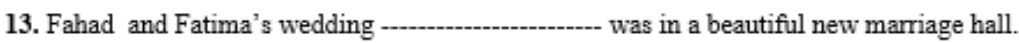

(house / ceremony / system)

14. Tomorrow is my uncle's twenty fifth wedding

(ceremony / anniversary / day)

15. I gave my grandmother a bouquet of -.........-on Mother's Day. (flowers / sweets / apples)

16. We always have a --all) (party / invitation / call)

17. People like to play --on each other on April Fools' Day. (football / tricks / basketball

\section{Choose the correct word/phrases from the box.}

Homework, healthier, more free time, appearance, somewhere else

18. My friend will look smarter if he changes his

19. It's hot and humid in Jeddah. I would like to go

20. If he takes rich diet he will be

21 . He was too busy last week but now he has

22 . I don't like to do any during semester break.

\section{Appendix. 4 grammar test}

\begin{tabular}{|c|}
\hline Quiz: Indirect Questions: Choose the correct answer. \\
\hline 1 - I have no idea - (where she is / where is she) \\
\hline 2 - I asked them where -- going? (were they/ they were) \\
\hline 3 - Can you explain why -................ \\
\hline $4-$ She asked me where --..-....- \\
\hline 5-Could you tell me where - - \\
\hline $6-$ My teacher asked me what time --..-- the college? ( did I reach $/ \mathrm{I} r$ \\
\hline
\end{tabular}

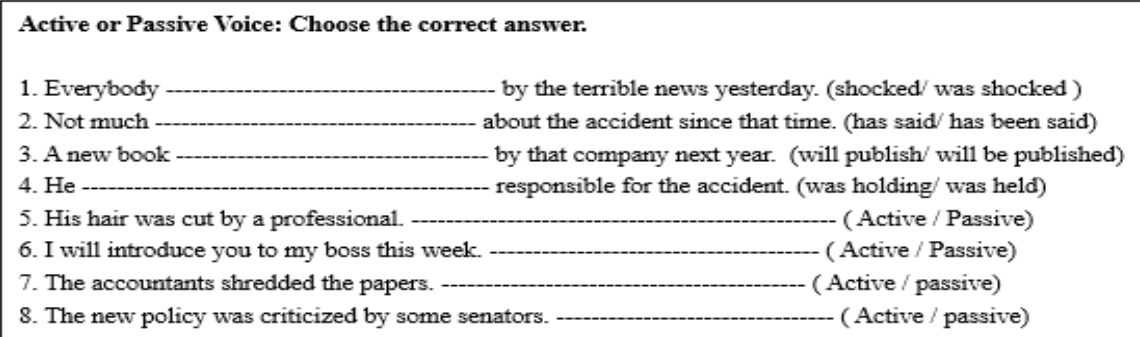

